\title{
COBALT FERRITE NANOCOMPOSITE AS ELECTROCHEMICAL SENSOR FOR THE DETECTION OF GUANINE, URIC ACID AND THEIR MIXTURE
}

\author{
Yogendra Kumar ${ }^{1}$, Vivek Sharma ${ }^{1}, V^{2}$ inod Kumar Vashistha1, \\ Rajasekhar VSR Pullabhotla ${ }^{2}$, Dipak Kumar Das ${ }^{1, \otimes}$
}

https://doi.org/10.23939/chcht15.04.520

\begin{abstract}
Cobalt ferrite nanocomposite was synthesized and characterized by analytical techniques such as FESEM, EDS and XRD. The average crystallite size was found to be in the range of $10-12 \mathrm{~nm}$ with a cubic structure. Further, the nanocomposite was used for the detection of guanine (GU) and uric acid (UA) and found to be an efficient electrode modifier. The lower limit of detection for GU and UA was found to be $300 \mathrm{nM}$ and $400 \mathrm{nM}$, respectively.
\end{abstract}

Keywords: electro-catalyst, nanoparticles of cobalt ferrite, electrochemical determination, guanine, uric acid.

\section{Introduction}

For determination of drug/bio molecules at low concentration it is very essential to develop cheap and sensitive electrode for pharmaceutical industry and clinical purpose. Although, conventional techniques are available for determination of bio molecules but these ones are expensive. Hence, the electrochemical techniques received the tremendous attention for few decades due to advantages like fast response, better selectivity, high sensitivity and low cost. Several materials like Co doped $\mathrm{CeO}_{2}$ nanoparticles (nps) [1], MWCNT-Fe $\mathrm{O}_{4} @$ PDA-Ag nanocomposite [2], nitrogen doped graphene nps [3], reduced graphene oxide [4], nickel telluride and cobalt telluride nps [5], $\mathrm{PbTe} / \mathrm{GP}$ electrode [6], glassy carbon electrode fabricated with zinc oxide [7], lanthanideorthoferrites $\left(\mathrm{XFeO}_{3} / \mathrm{GP}\right)$ [8-10], and urease immobilized biosensor for determination of urea [11] have been used as electrode materials.

Herein, we report the simple synthesis method of cobalt ferrite nanoparticles by a combustion technique using cobalt nitrate and ferric nitrate as precursors in the presence of mono-ethanolamine and sugar. The synthesized

\footnotetext{
${ }^{1}$ Department of Chemistry, GLA University, Mathura, India 281406

${ }^{2}$ Department of Chemistry, University of Zululand, South Africa

deepak.das@gla.ac.in

(c) Kumar Y., Sharma V., Vashistha V., Pullabhotla VSR., Das D., 2021
}

material was used as the electrode modifier with a graphite powder to prepare an electrode for detection of guanine (GU) and uric acid (UA) individually, as well as in the mixture by a cyclic voltammeter (CV) and differential pulse voltammetry (DPV) techniques.

\section{Experimental}

\subsection{Chemicals and Reagents}

Cobalt nitrate $\left(\mathrm{Co}\left(\mathrm{NO}_{3}\right)_{2} \cdot 6 \mathrm{H}_{2} \mathrm{O}\right)$, iron nitrate $\left[\mathrm{Fe}\left(\mathrm{NO}_{3}\right)_{3} \cdot 9 \mathrm{H}_{2} \mathrm{O}\right]$, nitric acid $\left(\mathrm{HNO}_{3}\right)$, paraffin oil and ethanolamine $\left(\mathrm{HOCH}_{2} \mathrm{CH}_{2} \mathrm{NH}_{2}\right)$ were purchased from Merck (India); graphite flakes, uric acid $\left(\mathrm{C}_{5} \mathrm{H}_{4} \mathrm{~N}_{4} \mathrm{O}_{3}\right)$, and guanine $\left(\mathrm{C}_{5} \mathrm{H}_{5} \mathrm{~N}_{5} \mathrm{O}\right)$ were procured from Sigma Aldrich, USA. All the reagents were of analytical grade and used without further purification, all solutions were prepared using double distilled water.

\subsection{Synthesis of Lanthanide Orthoferrites Nanoparticles}

Cobalt nitrate $(1.0 \mathrm{mM})$ was dissolved in $50 \mathrm{ml}$ of double distilled water in a beaker and ferric nitrate $(2.0 \mathrm{mM})$, nitric acid $(3.5 \mathrm{mM})$, ethanolamine $(1.7 \mathrm{mM})$ and sugar $(2.5 \mathrm{mM})$ were added in the above solution. The solution was then kept on a hot plate at $423 \mathrm{~K}$ until evaporated to dryness with the evolution of nitrogen oxides gases. A black fluffy mass was obtained in a beaker which was calcined at $873 \mathrm{~K}$ for $6 \mathrm{~h}$ to get nanoparticles of cobalt ferite.

\subsection{Preparation of Electrode}

Thoroughly grinded graphite powder and synthesized Np of cobalt ferrites in the ratio of $4: 1(\mathrm{w} / \mathrm{w})$ with a few drop of paraffin oil were taken in a mortar and pastel to make a uniform paste. The paste was then poured and packed tightly into the capillary glass tube $(2 \mathrm{~mm}$ inner diameter). A platinum wire was inserted from the back side of the capillary tube for electrical contact. 
Similar fabrication process was followed for the preparation of bare GP electrodes. Prepared electrode's surface was cleaned by $0.3 \mathrm{mM}$ and $0.05 \mathrm{mM} \mathrm{Al}_{2} \mathrm{O}_{3}$ slurry. Finally the electrode was rinsed with ethanol and dried under $\mathrm{N}_{2}$ atmosphere prior to experimentation.

\subsection{Apparatus and Measurement}

The morphology and size of the synthesized nanocomposite were determined by Hitachi SU-8010 field emission scanning electron microscope (FESEM) along with Bruker's energy-dispersive X-ray spectroscopy detector (EDS), model being XFlash 6130. A three electrode system, Autolab Potentiostate/Galvanostate 101 (Netherlands) was used for all electrochemical measurements. In this system the $\mathrm{Ag} / \mathrm{AgCl}$ electrode and $\mathrm{Pt}$ electrode were used as a reference electrode and a counter electrode, respectively. The electrochemical study was carried out in $0.1 \mathrm{M}$ phosphate buffer of $\mathrm{pH} 5.0$ at $298 \pm 2 \mathrm{~K}$ with a scan rate of $100 \mathrm{mV} \cdot \mathrm{s}^{-1}$ for $\mathrm{CV}$ and $50 \mathrm{mV} \cdot \mathrm{s}^{-1}$ for DPV along with a voltage range from 0.2 to $0.8 \mathrm{~V}$ for $\mathrm{UA}$ and 0.7 to $1.3 \mathrm{~V}$ for $\mathrm{GU}$, respectively, for $\mathrm{CV}$ experiments. For simultaneous determination of $\mathrm{UA}$ and $\mathrm{GU}$ at $\mathrm{CoFe}_{2} \mathrm{O}_{4} / \mathrm{GP}$ electrode, the voltage range was maintained from 0.2 to $1.4 \mathrm{~V}$ for both $\mathrm{CV}$ and DPV techniques.

\section{Results and Discussion}

\subsection{XRD Analysis of Cobalt Ferrite Nanocomposites}

Crystal structure and phase purity of synthesized nanocomposite were determined by $\mathrm{X}$-Ray powder diffraction (XRD) with $\mathrm{Cu} \mathrm{K} \alpha$ radiation $(\lambda=1.5406 \AA)$. The average crystallite size of nanoparticles was calculated from the full width at half maxima (FWHM) of the diffraction peak by a Debye-Scherrer method [12] by the following equation $D=K \lambda / \beta \cos \theta$, where $D$ is an average crystallite size, $\beta$ is a full width at half maxima (FWHM), $\lambda$ is a wavelength of X-rays $(\lambda 1 / 4=1.5406 \AA), \theta$ is a diffraction angle, and $k$ is a constant value which depends on several factors including the Miller index. The calculated crystal sizes of the lanthanide ferrite nano particles $(D)$ have been found to be in the range of 10 $12 \mathrm{~nm}$ with a cubic crystal structure.

\subsection{FESEM and EDS Study of Cobalt Ferrite Nanocomposites}

The size and morphology of the synthesized nanocomposites were characterized by FESEM and EDS techniques. Nanocomposites having the size of 10-15 nm have been found to have mostly a cubic shape. Fig. 1a represents the FESEM image of the synthesized nanocomposites and Fig. $1 \mathrm{~b}$ represents EDS image. The EDS image shows the purity of the synthesized material.

\subsection{Electrochemical Studies of $\mathrm{npCoFe}_{2} \mathrm{O}_{4} / \mathrm{GP}$ and Bare GP Electrode}

Electrochemical behavior of prepared electrodes have been investigated using a standard $\left[\mathrm{Fe}(\mathrm{CN})_{6}\right]^{-4} /$ $\left[\mathrm{Fe}(\mathrm{CN})_{6}\right]^{-3}$ redox system. The cyclic voltammograms at bare GP and $\mathrm{npCoFe}_{2} \mathrm{O}_{4} / \mathrm{GP}$ electrodes for $3 \mathrm{mM}$ $\mathrm{K}_{4}\left[\mathrm{Fe}(\mathrm{CN})_{6}\right]$ solution are shown in Fig. 2. Electron transfer at the working electrode depends on the value of the peak potential separation $(\Delta E p)$. According to a Velasco equation the electron transfer is more efficient due to a low value of peak potential separations [13]. $\Delta E p$ at both electrodes like $\mathrm{npCoFe}_{2} \mathrm{O}_{4} / \mathrm{GP}$ and bare GP electrodes are found to be 92 and $106 \mathrm{mV}$, respectively. From the above result it can be concluded that the npCoFe ${ }_{2} \mathrm{O}_{4} / \mathrm{GP}$ electrodes possess better electrochemical activity than bare GP electrode due to the lower $\Delta E p$. It is noteworthy that due to less $\Delta E p \quad(92 \mathrm{mV})$ of the npCoFe $\mathrm{O}_{4} / \mathrm{GP}$, it exhibited excellent sensor activities towards UA and GU in a cyclic voltammetric analysis.

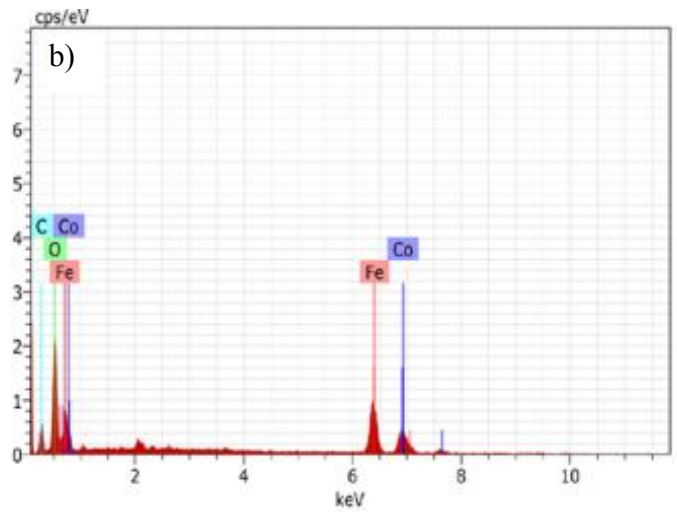

Fig. 1. SEM (a) and EDS (b) images of the synthesized $\mathrm{CoFe}_{2} \mathrm{O}_{4}$ nanoparticles 


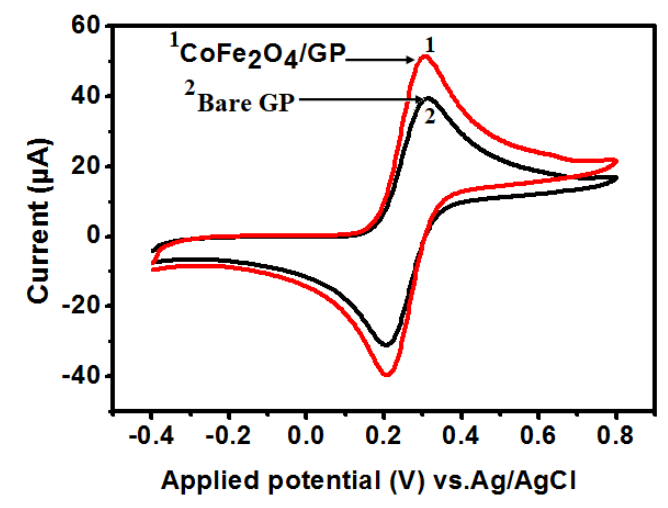

Fig. 2. $\mathrm{CV}$ plot at $\mathrm{npCoFe}_{2} \mathrm{O}_{4} / \mathrm{GP}$ (peak 1) and bare GP electrode (peak 2) for $3 \mathrm{mM}$ $\left[\mathrm{Fe}(\mathrm{CN})_{6}\right]^{-4} /\left[\mathrm{Fe}(\mathrm{CN})_{6}\right]^{-3}$ redox system

\subsection{Electrocatalytic Oxidation of UA and $\mathrm{GU}$ at $\mathrm{npXFeO} / 3 / \mathrm{GP}$ and Bare GP Electrodes}

Electrocatalytic behavior of UA and GU (individually as well as in the mixture) has been studied by a cyclic voltammetry (CV) and differential pulse voltammetry (DPV) measurements at bare GP and npCoFe $\mathrm{O}_{4} / \mathrm{GP}$ electrodes (Fig. 3). The cyclic voltammograms at bare GP and $\mathrm{npCoFe}_{2} \mathrm{O}_{4} / \mathrm{GP}$ are shown in Fig. 3a for UA, in Fig. 3b for GU and in Fig. 3c for the mixture of UA and GU. Both bio-molecules (UA and GU) depicted irreversible oxidation characters at bare GP and $\mathrm{npCoFe}_{2} \mathrm{O}_{4} / \mathrm{GP}$ electrodes. The oxidation peak potentials at npCoFe $\mathrm{O}_{4} / \mathrm{GP}$ electrodes are 676 and $1042 \mathrm{mV}$ for UA and GU, respectively, whereas at bare GP -658 and $1054 \mathrm{mV}$, respectively. All the $\mathrm{CV}$ measurements were carried out by maintaining a scan rate $100 \mathrm{mV} \mathrm{s}^{-1}$, and DPV experiment was carried out at the scan rate $50 \mathrm{mV} \mathrm{s}^{-1}$, step potential $5 \mathrm{mV}$, modulation amplitude $40 \mathrm{mV}$, modulation time $0.02 \mathrm{~s}$ and interval time $0.1 \mathrm{~s}$. For the individual determination of UA and GU, the cyclic voltammograms were operated in the voltage ranges from 0.35 to $0.85 \mathrm{~V}$ and 0.65 to $1.35 \mathrm{~V}$, respectively. But for simultaneous determination of $\mathrm{UA}$ and $\mathrm{GU}$ at all $\mathrm{npCoFe} \mathrm{O}_{4} / \mathrm{GP}$ electrodes, the voltage range was maintained from 0.35 to $1.4 \mathrm{~V}$ for both techniques like CV and DPV with a buffer solution of $\mathrm{pH} 5.0$ as a supporting electrolyte.
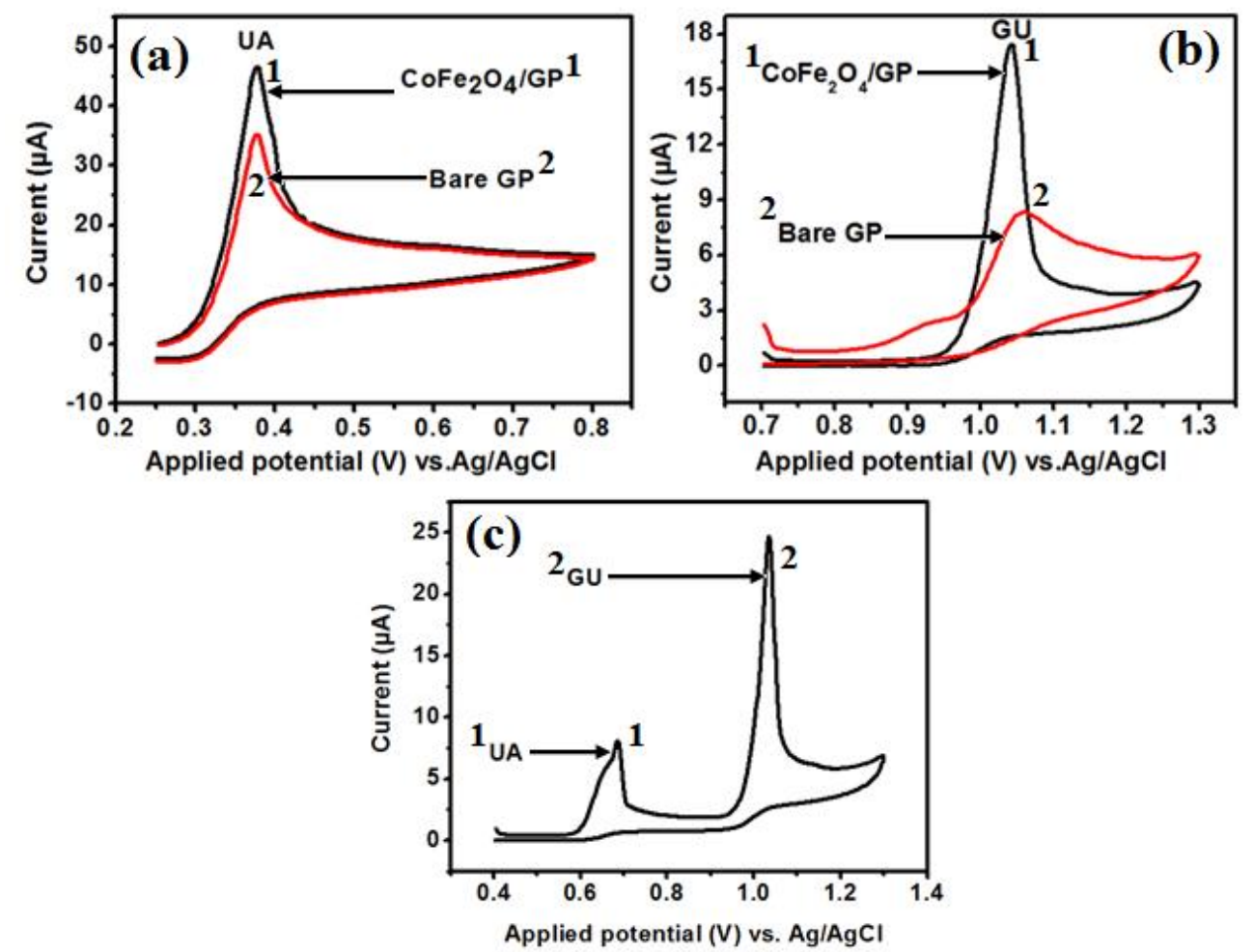

Fig. 3. CV plots of $0.1 \mathrm{mM} \mathrm{UA} \mathrm{(a)} \mathrm{at} \mathrm{npCoFe}_{2} \mathrm{O}_{4} / \mathrm{GP}$ electrodes (peak 1) and at bare GP electrode (peak 2); $0.1 \mathrm{mM} \mathrm{GU}$ (b) at npCoFe $\mathrm{O}_{4} / \mathrm{GP}$ electrodes (peak 1) and at bare GP electrode (peak 2); CV plot of $0.1 \mathrm{mM} \mathrm{UA}$ and $0.1 \mathrm{mM} \mathrm{GU}$ mixture (c) at npCoFe $\mathrm{O}_{4} / \mathrm{GP}$ electrodes in $0.1 \mathrm{M}$ phosphate buffer solution of $\mathrm{pH} 5.0$ maintaining CV scan rate of $100 \mathrm{mV} \cdot \mathrm{s}^{-1}$ 


\section{5. $\mathrm{pH}$ and Scan Rate Effect on the Oxidation of UA and GU}

The $\mathrm{pH}$ value of supporting electrolyte plays the key role in the oxidation of bio-molecules. Therefore, the effect of $\mathrm{pH}$ on the peak potential and peak current value of UA and GU was studied by a cyclic voltammetry using $0.1 \mathrm{M}$ phosphate buffer solution having the $\mathrm{pH}$ range from 4 to 7 . It was observed that the oxidation peak potential value shifted negatively with the increase in $\mathrm{pH}$ of supporting electrolyte for both bio-molecules (GU and UA). The maximum peak current was observed at $\mathrm{pH} 5$ and it decreased when $\mathrm{pH}$ of the solution was further increased. It might be due to the multi basic character of bio-molecules and the results are in agreement with the previous report for determination of these molecules [14-15]. Although, the exact reason of the phenomenon is unclear, this may be due to the formation of various kinds of cationic, anionic and dimeric species of analyte molecules, the results are shown in Fig 4a. The scan rate effect on the oxidation of UA and $\mathrm{GU}$ at $\mathrm{npCoFe} \mathrm{O}_{2} / \mathrm{GP}$ electrodes has been investigated by changing the scan rate from 5 to $500 \mathrm{mV} \cdot \mathrm{s}^{-1}$. It was observed that there was a linear increment in the peak current with the increase in the scan rate (Fig. 4b,c). It infers that the oxidation process is the diffusion controlled at the surface of modified electrodes.
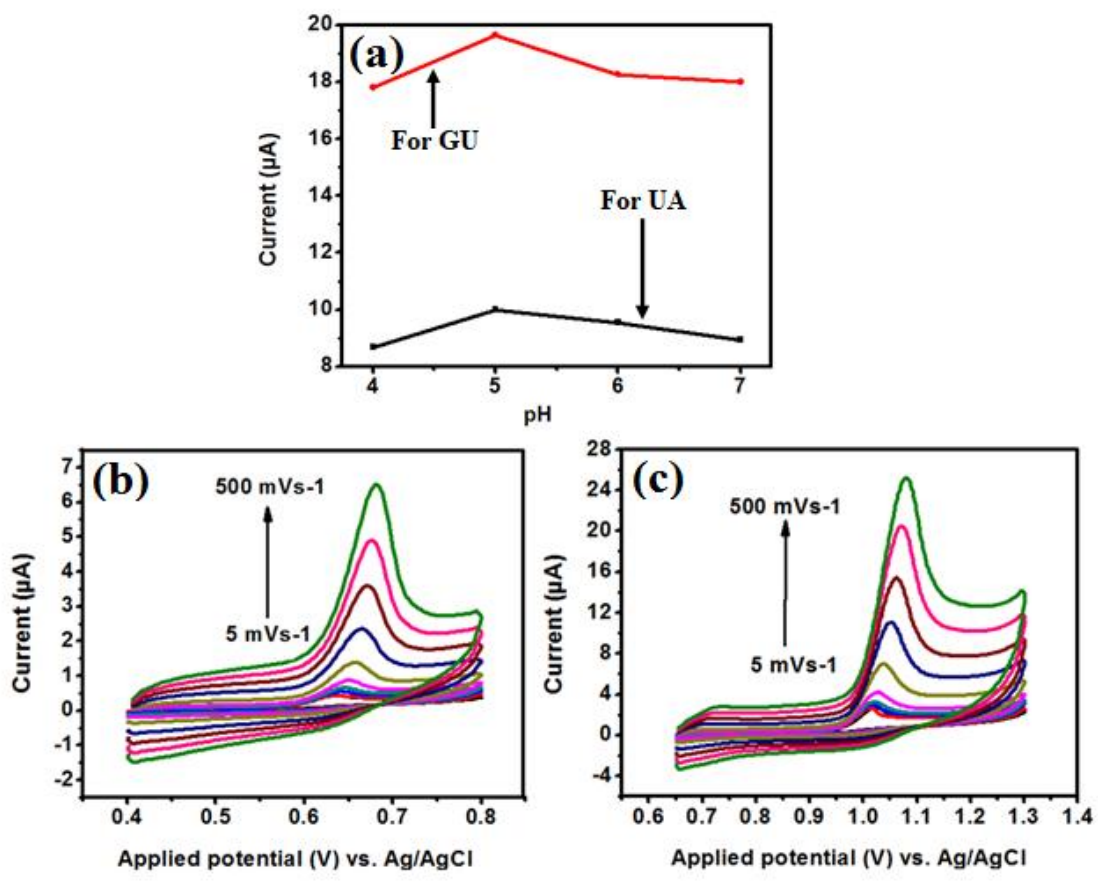

Fig. 4. $\mathrm{pH}$ variation (a) $v s$. current plot in a phosphate buffer solution from $\mathrm{pH} 4$ to $\mathrm{pH} 7$ and scan rate variation from 5 to $500 \mathrm{mV} \cdot \mathrm{s}^{-1}$ for $\mathrm{UA}(\mathrm{b})$ and $\mathrm{GU}$ (c) at $\mathrm{CoFe}_{2} \mathrm{O}_{4} / \mathrm{GP}$ electrode
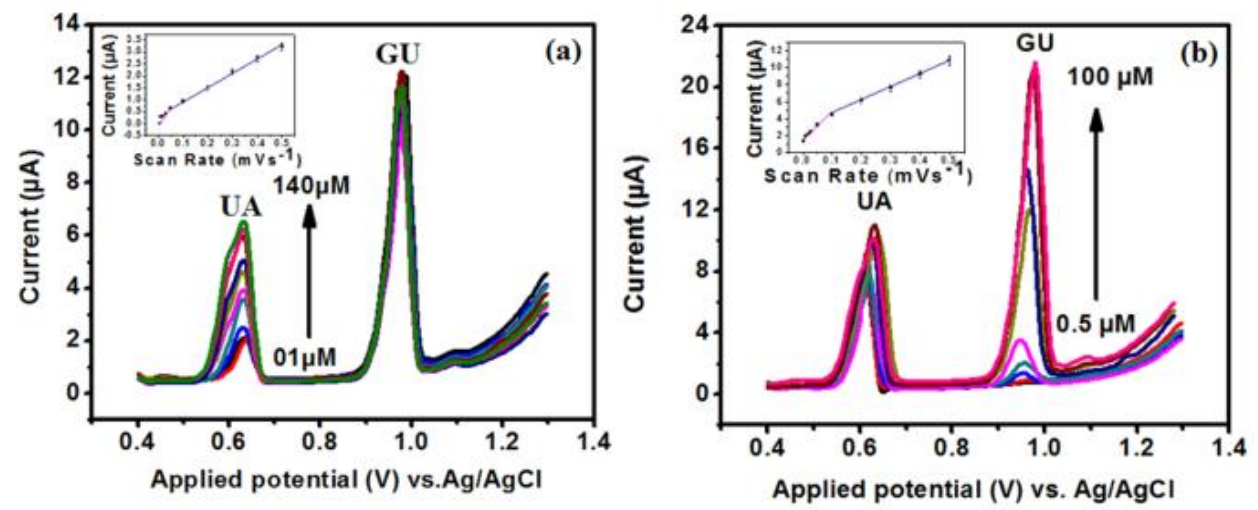

Fig. 5. UA (a) varied from 1 to $140 \mu \mathrm{M}$ at npCoFe $\mathrm{O}_{4} / \mathrm{GP}$ electrode with keeping GU fixed as $100 \mu \mathrm{M}$; GU (b) varied from 0.5 to $100 \mu \mathrm{M}$ at $\mathrm{npCoFe}_{2} \mathrm{O}_{4} / \mathrm{GP}$ electrode with keeping UA fixed as $100 \mu \mathrm{M}$; in the inset the current value in $\mu \mathrm{A}$ vs. scan rate 


\subsection{Simultaneous Determination of UA and GU}

Optimum CV experiment was performed for simultaneous determination of UA and GU in the mixture at $\mathrm{npCoFe}_{2} \mathrm{O}_{4} / \mathrm{GP}$ electrode at the preliminary stage. But for the better resolution and higher peak current density, the DPV technique has been preferred. A controlled DPV experiment varying voltage from 0.35 to $1.4 \mathrm{~V}$ has been performed at $\mathrm{npCoFe}_{2} \mathrm{O}_{4} / \mathrm{GP}$ electrode, by changing the concentration of one biomolecule while keeping the second one fixed. Fig. 5a and $5 \mathrm{~b}$ demonstrates the DPV voltammograms of fixed concentration of GU $(100 \mu \mathrm{M})$ with various concentration of UA (from 1 to $140 \mu \mathrm{M}$ ), as well as a fixed concentration of UA $(100 \mu \mathrm{M})$ with various concentration of $\mathrm{GU}$ (from 0.5 to $100 \mu \mathrm{M}$ ), respectively. It was observed that the oxidation peak current $\left(I_{\mathrm{UA}}\right)$ increased linearly with the increase in the concentration of UA $\left(C_{\mathrm{UA}}\right)$. Similar observation was also found for GU variation. The first linearity range for UA was observed from 1 to $40 \mu \mathrm{M}\left(I_{\mathrm{UA}}\right) y=0.002_{\mathrm{UA}}+0.082$ $\left(R^{2}=0.891\right)$ and second linearity range was observed from 40 to $140 \mu \mathrm{M}\left(I_{\mathrm{UA}}\right) y=0.001_{\mathrm{UA}}+0.132$ $\left(R^{2}=0.976\right)$, the linearity range graph current versus scan rate for UA shown in the inset of Fig. 5a. The first linearity range for GU was observed from 0.5 to $40 \mu \mathrm{M}$ $\left(I_{\mathrm{GU}}\right) y=0.015_{\mathrm{GU}}-0.001\left(R^{2}=0.940\right)$ and the second linearity range was observed from 40 to $100 \mu \mathrm{M}\left(I_{\mathrm{GU}}\right)$ $y=0.009_{\mathrm{GU}}+0.272\left(R^{2}=0.998\right)$. The linearity range graph current versus scan rate for UA was shown in the inset of Fig. 5b. The lower detection limits were found to be 300 and $400 \mathrm{nM}$ for GU and UA, respectively, at the developed electrode.

\subsection{Comparative Study with a Previously Developed Electrode}

The developed cobalt ferrite nanocomposite $\left(\mathrm{npCoFe} \mathrm{O}_{2} / \mathrm{GP}\right)$ modified graphite paste electrode was found to be better for detection of GU and UA when compared with literature reported electrodes (Table 1). The cobalt ferrite modified graphite paste electrode $\left(\mathrm{npCoFe} \mathrm{O}_{2} / \mathrm{GP}\right)$ showed the linearity range from 0.5 to $100 \mu \mathrm{M}$ and 1 to $140 \mu \mathrm{M}$ for GU and UA, respectively, with a very low detection limit of 300 and $400 \mathrm{nM}$ for GU and $U A$, respectively.

\subsection{Stability, Repeatability, Reproducibility and Sensitivity of Prepared Electrode}

The stability of prepared electrode has been investigated after storing the developed electrode at $303 \pm 1 \mathrm{~K}$ for 30 days. When compared with the initial value, it was found to retain more than $96 \%$ of sensing capacity. Repeatability of prepared electrode was investigated by observing the electrode response by repeating up to 20 times and no notable change in the sensitivity of electrode was observed. For the reproducibility of electrodes, five electrodes of $n p \mathrm{noFe}_{2} \mathrm{O}_{4} / \mathrm{GP}$ were prepared using similar methods and the sensitivity of electrodes towards the detection of biomolecules has been investigated, and was found to produce almost similar response. Hence, it may be concluded that the electrodes have good stability, reproducibility, repeatability and sensitivity.

\subsection{Real Sample Analysis Using $\mathrm{CoFe}_{2} \mathrm{O}_{4} / \mathrm{GP}$ Modified Electrode}

For the practical performance of the working electrodes in a real sample, urine and human serum samples were selected. The samples have been centrifuged at $4000 \mathrm{rpm}$ and collected by a dropper and diluted with a buffer solution of $\mathrm{pH} 5.0$ to fit the calibration curve. It was observed (Table 2) that the recovery values of UA in urine and human serum samples at $\mathrm{npCoFe} \mathrm{O}_{4} / \mathrm{GP}$ electrodes were 101.5 and $99.7 \%$, respectively. Hence, it may be concluded that the developed electrode can be used for diagnostic purpose in the determination of these bio molecules.

Table 1

Comparison of developed electrode with literature reports

\begin{tabular}{|c|c|c|c|c|c|}
\hline \multirow{2}{*}{ Electrodes } & \multicolumn{2}{|c|}{ Guanine } & \multicolumn{2}{c|}{ Uric acid } & \multirow{2}{*}{ References } \\
\cline { 2 - 5 } & $\begin{array}{c}\text { Linear range, } \\
\mu \mathrm{M}\end{array}$ & $\begin{array}{c}\text { Detection limit, } \\
\mathrm{nM}\end{array}$ & $\begin{array}{c}\text { Linear range, } \\
\mu \mathrm{M}\end{array}$ & $\begin{array}{c}\text { Detection limit, } \\
\mathrm{nM}\end{array}$ & \\
\hline $\mathrm{TAN}-\mathrm{Ag} \mathrm{NP}-\mathrm{PANF} / \mathrm{CPE}$ & $0.9-140$ & 3000 & - & - & {$[16]$} \\
\hline $\mathrm{PANI} / \mathrm{MnO}_{2} / \mathrm{GCE}$ & $10-100$ & 4800 & - & - & {$[17]$} \\
\hline $\mathrm{p}-\mathrm{PTSA} / \mathrm{GCE}$ & $10-100$ & 350 & $10-100$ & 5880 & {$[18]$} \\
\hline $\mathrm{Pimox} \mathrm{GO} / \mathrm{GCE}$ & $3.3-103.3$ & 480 & $3.6-249.6$ & 590 & {$[19]$} \\
\hline $\mathrm{UO}$ x-poly$(4-\mathrm{ASA})-\mathrm{PB}-\mathrm{CSPE}$ & & & $10-200$ & 3000 & {$[20]$} \\
\hline $\mathrm{GO} / \mathrm{Fe}_{3} \mathrm{O}_{4} @ \mathrm{SiO}_{2} / \mathrm{CSPE}$ & - & - & $0.75-300$ & 570 & {$[21]$} \\
\hline $\mathrm{npCoFe}_{2} \mathrm{O}_{4} / \mathrm{GP}$ & $0.5-100$ & 300 & $01-140$ & 400 & Our method \\
\hline
\end{tabular}


Cobalt Ferrite Nanocomposite as Electrochemical Sensor for The Detection of Guanine, Uric Acid... 525

Table 2

Validation parameters of the prepared electrodes

\begin{tabular}{|c|c|c|c|c|c|c|}
\hline Electrode & Sample & $\begin{array}{l}\text { Original/diluted } \\
\text { sample, } \mu \mathrm{M}\end{array}$ & Spiking, $\mu \mathrm{M}$ & Found, $\mu \mathrm{M}$ & R.S.D ${ }^{1}, \%$ & Recovery $^{2}, \%$ \\
\hline \multirow{3}{*}{$\begin{array}{c}\mathrm{CoFe}_{2} \mathrm{O}_{4} / \mathrm{GP} \\
\mathrm{nps}\end{array}$} & \multicolumn{6}{|c|}{ Urine sample } \\
\hline & UA & 20 & 30 & 50.5 & 1.92 & 101.5 \\
\hline & GU & 0 & 50 & 50.1 & 1.54 & 100.2 \\
\hline \multirow{3}{*}{$\begin{array}{c}\mathrm{CoFe}_{2} \mathrm{O}_{4} / \mathrm{GP} \\
\text { nps }\end{array}$} & \multicolumn{6}{|c|}{ Human serum sample } \\
\hline & UA & 20 & 30 & 49.8 & 1.4 & 99.7 \\
\hline & GU & 0 & 50 & 50.3 & 1.7 & 99.2 \\
\hline
\end{tabular}

Notes: ${ }^{1}$ Relative standard deviation; ${ }^{2}$ Recovery $=\frac{\text { Found }- \text { Diluted biological } \frac{\text { fluids }}{\text { pharmaceutical }} \text { sample }}{\text { Spiking }} \cdot 100 \%$

\section{Conclusions}

In this paper, we report the simple synthesis procedure for cobalt ferrite nanocomposite. The synthesized material was characterized by XRD, FESEM and TEM techniques and was found to have a cubic structure with the size ranging from 10 to $12 \mathrm{~nm}$. The synthesized nanocomposite was used as the electrode modifier with a graphite paste and used as a sensor for determination of biomolecules like UA and GU in biofluids. CV and DPV techniques were used for the electrochemical measurements of these molecules. The synthesized $n \mathrm{nCoFe}_{2} \mathrm{O}_{4}$ based electrodes exhibited the significant results in the determination of UA and GU with a low detection limit (300 and $400 \mathrm{nM}$ for GU and UA, respectively), better than previous reports. The main advantages of the composite electrode are simple synthesis protocol and superior sensitivity of detection and are therefore suitable for application in the field of clinical and pharmaceutical industry.

\section{Acknowledgments}

The authors are thankful to GLA University, Mathura (India) for providing financial support and Jadavpur University, Kolkata (India) for technical support.

\section{References}

[1] Lavanya N., Sekar C., Murugan R., Ravi G.: Mater. Sci. Eng. C, 2016, 65, 278. https://doi.org/10.1016/j.msec.2016.04.033

[2] Yari A., Derki S.: Sensor Actuat. B-Chem., 2016, 227, 456. https://doi.org/10.1016/j.snb.2015.12.088

[3] Li J., Jiang J., Feng H. et al.: RSC Adv., 2016, 6, 31565. https://doi.org/10.1039/C6RA01864E

[4] Wang H., Ren F., Wang C. et al.: RSC Adv., 2014, 4, 26895. https://doi.org/10.1039/C4RA03148B

[5] Pradhan S., Das R., Biswas S. et al.: Electrochim. Acta, 2017, 238, 185. https://doi.org/10.1016/j.electacta.2017.04.023

[6] Pradhan S., Biswas S., Das D. et al.: New J. Chem., 2018, 42, 564. https://doi.org/10.1039/C7NJ03308G

[7] Chokkareddy R., Bhajanthri N., Redhi G.: Indian J. Chem. A, 2018, 57, 887. http://nopr.niscair.res.in/handle/123456789/44743
[8] Kumar Y., Pradhan S., Pramanik S. et al.: J. Electroanal. Chem., 2018, 830-831, 95. https://doi.org/10.1016/j.jelechem.2018.10.021

[9] Kumar Y., Singh P., Pramanik P., Das D.: J. Sci. Ind. Res., 2019,

78, 177. http://nopr.niscair.res.in/handle/123456789/45941

[10] Kumar Y., Pramanik P., Das D.: Heliyon, 2019, 5, e02031.

https://doi.org/10.1016/j.heliyon.2019.e02031

[11] Sihombing K., Tamba M., Marbun W., Situmorang M.: Indian J.

Chem. A, 2018, 57, 175.

http://nopr.niscair.res.in/handle/123456789/43627

[12] Cullity B., Stock S.: Elements of X-ray Diffraction. Addison-

Wesley, Boston 2001.

[13] Zhang X., Duan S., Xu X. et al.: Electrochim. Acta, 2011, 56,

1981. https://doi.org/10.1016/j.electacta.2010.11.048

[14] Sun W., Liu J., Ju X. et al.: Ionics, 2013, 19, 657.

https://doi.org/10.1007/s11581-012-0789-6

[15] Rezaei B., Khosropour H., Ensafi A. et al.: RSC Adv., 2015, 5,

75756. https://doi.org/10.1039/C5RA15845A

[16] Yari A., Saidikhah M.: J. Electroanal. Chem., 2016, 783, 288.

https://doi.org/10.1016/j.jelechem.2016.10.063

[17] Hui Y., Ma X., Hou X. et al.: Ionics, 2015, 21, 1751.

https://doi.org/10.1007/s11581-014-1343-5

[18] Jesny S., Menon S., Girish Kumar K.: RSC Adv., 2016, 6,

75741. https://doi.org/10.1039/C6RA13567F

[19] Liu X., Zhang L., Wein S. et al.: Biosens. Bioelectron., 2014, 57,

232. https://doi.org/10.1016/j.bios.2014.02.017

[20] da Cruz F., Paula F., Franco D. et al.: J. Electroanal. Chem.,

2017, 806, 172. https://doi.org/10.1016/j.jelechem.2017.10.070

[21] Beitollahi H., GarkaniNejad F., Shakeri S.: Anal. Methods, 2017, 9, 5541. https://doi.org/10.1039/C7AY01226H

Received: February 13, 2020 / Revised: March 19, 2020 / Accepted: August 31, 2020

\section{НАНОКОМПОЗИТ ФЕРИТУ КОБАЛЬТУ ЯК ЕЛЕКТРОХІМІЧНИЙ СЕНСОР ДЛЯ ВИЗНАЧЕННЯ ГУАНІНУ, СЕЧОВОЇ КИСЛОТИ ТА ЇХ СУМІШІ}

Анотація. Синтезовано нанокомпозит фериту кобальmу, який охарактеризований аналітичними методами, такими як FESEM, EDS та XRD. Встановлено кубічну структуру кристалітів із середнім розміром від 10 до 12 нм. Встановлено, щзо синтезований нанокомпозит може бути використаний для виявлення гуаніну (GU) та сечової кислоти (UA) i є ефективним модифікатором електродів. Визначено, що нижня межа виявлення для GU та UА становить 300 нМ та 400 нМ, відповідно.

Ключові слова: електрокаталізатор, наночастинки фериту кобальту, електрохімічне визначення, гуанін, сечова кислота. 